\title{
Gabapentin for the treatment of behavioral and psychological symptoms of dementia
}

\author{
Rajesh R. Tampi ${ }^{1 \#}$, Banu Ozkan ${ }^{2}$, Deena Williamson ${ }^{3}$ \\ ${ }^{1}$ Department of Psychiatry, Yale University School of Medicine, New Haven, USA; \\ *Corresponding Author: rajesh.tampi@yale.edu \\ ${ }^{2}$ Department of Psychiatry, University of Maryland, Baltimore, USA \\ ${ }^{3}$ Saint Francis Hospital and Medical Center, Hartford, USA
}

Received 13 July 2012; revised 18 August 2012; accepted 26 August 2012

\begin{abstract}
Objective: To examine the efficacy of gabapentin for the treatment of behavioral and psychological symptoms of dementia (BPSD). Design: A retrospective chart review. Settings: Tertiary care geriatric psychiatry inpatient unit. Participants: 230 patients with BPSD. Measurements: The socio-demographic information, type of behaviors, co-morbid psychiatric and medical diagnoses, daily doses of medications and side-effects were recorded. Results: Of the 230 patients, 22 were treated with gabapentin. Twenty of these patients were on a combination of gabapentin and an antipsychotic medication while two patients were treated with gabapentin monotherapy. Eighteen of the 20 patients in the combination group tolerated the treatments with little or no side effects as did the two patients in the monotherapy group. Conclusions: Gabapentin may be a safe option for the treatment of BPSD in combination with antipsychotic medications. Gabapentin may also be effective as monotherapy in certain patients with BPSD.
\end{abstract}

Keywords: Behavioral and Psychological Symptoms of Dementia; Neuropsychiatric Symptoms of Dementia; Anticonvulsants; Gabapentin

\section{INTRODUCTION}

Behavioral and psychological symptoms of dementia (BPSD) are a heterogeneous group of non-cognitive symptoms and behaviors that occur in patients with dementia [1]. BPSD does not reflect a specific diagnostic entity, but describes an important clinical dimension of

\footnotetext{
*The other authors have no financial disclosures to make and there are no conflicts of interest to report in the conduct of this study.

"Corresponding author.
}

dementia which is often the triggering event for its recognition and referral to the specialist service [2]. The development of BPSD is associated with greater impairment in activities of daily living, more cognitive decline and poorer quality of life, institutionalization and is also a major risk factor for caregiver burden [3]. In this regard, BPSD are more important than the progressive cognitive deficits of the disease, and for the care of the patients with $\mathrm{AD}$ [3].

Treatments available for BPSD are currently not standardized and include various non-pharmacological and pharmacological approaches [3,4] Pharmacotherapy is usually initiated when symptoms have failed to respond to non-pharmacological interventions and are not attributable to an underlying medical condition or medication effect [3,4]. A variety of medications have been used to treat BPSD, including typical and atypical antipsychotics, antidepressants, anticonvulsant mood stabilizers, cholinesterase inhibitors, benzodiazepines and other drugs $[3,4]$.

While the benefits of antipsychotics and anticonvulsants like valproic acid and carbamazepine in the treatment of BPSD are not clear, gabapentin, another anticonvulsant may be a potential treatment for the treatment of these symptoms [3,4]. Gabapentin is structurally related to GABA and it probably acts by interfering with the calcium channels to alter transmitter release. It is commonly used as an adjunctive therapy for partial seizures. Gabapentin is eliminated unchanged renally, and its clearance is expected to parallel the age-related decrease in glomerular filtration rate. The pharmacokinetics of gabapentin, specifically the lack of both hepatic metabolism and protein binding, makes gabapentin a drug that is potentially safer than the other anticonvulsant agents for the elderly population [5].

The efficacy of gabapentin in treating behavioral symptoms of dementia has been described in several case reports and open-label trials but its effect as an adjunct to antipsychotic treatment has not been studied [6,7]. The 
purpose of this report is to consider the efficacy of gabapentin as an adjunctive therapy to antipsychotics and also as monotherapy for behavioral and psychological symptoms of dementia.

\section{Methods}

The data for this case series is derived from a retrospective chart review of 230 demented inpatients, discharged between July 1st, 2002 and March 31st, 2007 from the Geriatric Psychiatry Unit of a University Hospital. All these patients were diagnosed with dementia according to the Diagnostic and Statistical Manual of Mental Disorders, Text Revision, 4th edition (DSMIV-TR) [8].

Medications given to treat these patients were evaluated and the charts of all patients who had BPSD and were treated with gabapentin were selected for this review. Patients were treated with gabapentin if they could not tolerate higher doses of the antipsychotic agents and need further stabilization of their behavioral problems. The socio-demographic information, co-morbid psychiatric and medical diagnoses, daily doses of gabapentin and antipsychotics, effects and side-effects of gabapentin were recorded.

As this was a retrospective chart review, a waiver of consent was obtained from the University Institutional Review Board for the conduct of this study.

\section{Results}

The total number of patients with dementia who were treated with gabapentin was twenty-two. Twenty of these patients were on a combination of atypical antipsychotic medication and gabapentin while two patients were treated with gabapentin monotherapy.

The average age of the patients in the study was $73 \pm$ 8.69 years. There were 15 male patients with an average age of 73.78 years and 7 female patients with an average age of 76.57 years. Of these 22 patients, 16 were Caucasian (M:F, 10:6), 3 were African America (3:0) and 3 Hispanic (2:1) (Table 1).

All patients had a diagnosis of dementia, of these, 12 patients had Alzheimer's disease, 6 had dementia of

Table 1. Demographic information of the patients.

\begin{tabular}{ccc}
\hline Sex & Male $(\mathbf{n}=\mathbf{1 5})$ & Female $(\mathbf{n}=\mathbf{7})$ \\
\hline Age (years) & 73.78 & 76.57 \\
Race & & \\
African-American & 3 & 0 \\
Hispanic & 2 & 1 \\
Caucasian & 10 & 6 \\
\hline
\end{tabular}

mixed type, 3 had vascular dementia and 1 patient had Lewy Body Dementia. Of the twenty-two patients, six had Folstein Mini Mental State Examination (MMSE) scores available [9]. The average MMSE score for these patients was $10.87 \pm 6.02$. Sixteen of the patients were unable to co-operate with the MMSE because of severe impairment in cognitive functioning and agitation.

Agitation (verbal aggression) was the most common behavior noted in these patients. Combative behavior (physical aggression) was seen in 18 of the 22 patients. A combination of agitation and physical aggression was seen in 11 of the 22 patients. Paranoid thoughts (5/22, $23 \%$ ) and inappropriate sexual behaviors (2/22, 9\%) were less commonly noted in these patients. Confusion as a complaint was noted only in 5 of the 22 patients (23\%).

A combination of gabapentin and an atypical antipsychotic medication was administered to the 20 patients. Eighteen of them tolerated this combination with no side effects. Two patients developed side-effects. One patient who was treated with $1800 \mathrm{mg} /$ day of gabapentin and 20 $\mathrm{mg} /$ day of olanzapine became lethargic. The dose of gabapentin was reduced to $400 \mathrm{mg}$ /day with a reduction in sedation. The other patient was being treated with 300 $\mathrm{mg} /$ day of gabapentin and $75 \mathrm{mg} /$ day quetiapine. Because of sedation, the dose of gabapentin was decreased to $200 \mathrm{mg} /$ day. None of the patients in the monotherapy group had any side-effects.

In the combination treatment group, 11 patients were on quetiapine, 6 were on olanzapine, 2 were on risperidone and 1 was on clozapine. Of the 22 patients, 10 were on Donepezil 5 - $10 \mathrm{mg} /$ day and 1 was on memantine and 1 was on both donepezil and memantine. One of the patients was on valproic acid for seizure disorder, and 2 of them were on both valproic acid and gabapentin for agitation and behavioral problems (Table 2).

Behavioral issues in of all the patients resolved with these treatments. Twenty patients were discharged to skilled nursing facilities, 1 patient went to an assisted living facility and 1 patient went home. The average length of stay for these patients was $23.23 \pm 5.66$ days.

\section{Discussion}

Although some psychotropic medications have been found to be helpful in the treatment of BPSD, none of them have proven efficacy and benign side-effect profiles [3,4]. Elderly patients also have more medical co-morbidities and are taking multiple medications. This puts them at higher risk for developing medical complications and medication side-effects along with drug-drug interactions. These issues must be considered while giving a new medication to the older patient $[3,4]$.

In this study, we used a combination of atypical anti- 
Table 2. Diagnosis, comorbidities and psychotropic medications.

\begin{tabular}{|c|c|c|c|c|c|c|c|}
\hline \multirow{2}{*}{$\begin{array}{l}\text { Age } \\
83\end{array}$} & \multirow{2}{*}{$\begin{array}{l}\text { Diagnosis } \\
\text { ementia; mixed } \\
\text { ype (AD an d } \\
\text { ascular type), } \\
\text { moderate }\end{array}$} & \multirow{2}{*}{$\begin{array}{c}\text { Comorbid medical illness } \\
\\
\text { anemia, post CVA, CAD, } \\
\text { chronic orthostatic hypotension, } \\
\text { hypertension, AF, CRI }\end{array}$} & \multirow{2}{*}{$\begin{array}{c}\begin{array}{c}\text { Comorbid } \\
\text { psychiatric } \\
\text { illness }\end{array} \\
\text { no }\end{array}$} & \multicolumn{4}{|c|}{ Psychotropic medications (name/daily dosages) } \\
\hline & & & & $\begin{array}{l}\text { Gabapentin } \\
400 \mathrm{mg}\end{array}$ & $\begin{array}{l}\text { Memantine } \\
20 \mathrm{mg}\end{array}$ & & \\
\hline 73 & $\begin{array}{l}\text { Dementia; } \\
\text { AD type }\end{array}$ & vitamin B12 deficiency & $\begin{array}{l}\text { MDD with } \\
\text { anxiety }\end{array}$ & $\begin{array}{l}\text { Gabapentin } \\
600 \mathrm{mg}\end{array}$ & $\begin{array}{l}\text { Donepezil } \\
5 \mathrm{mg}\end{array}$ & $\begin{array}{l}\text { Quetiapine } \\
400 \mathrm{mg}\end{array}$ & \\
\hline 76 & $\begin{array}{l}\text { Dementia; } \\
\text { AD type, } \\
\text { moderate }\end{array}$ & $\begin{array}{l}\text { hypertension, DM type II, } \\
\text { CRI, BPH, gout }\end{array}$ & no & $\begin{array}{l}\text { Gabapentin } \\
800 \mathrm{mg}\end{array}$ & $\begin{array}{l}\text { Olanzapine } \\
15 \mathrm{mg}\end{array}$ & & \\
\hline 67 & $\begin{array}{l}\text { Dementia; } \\
\text { AD type }\end{array}$ & $\begin{array}{l}\text { hypertension, urinary } \\
\text { incontinence, BPH }\end{array}$ & no & $\begin{array}{l}\text { Gabapentin } \\
500 \mathrm{mg}\end{array}$ & $\begin{array}{l}\text { Olanzapine } \\
15 \mathrm{mg}\end{array}$ & $\begin{array}{l}\text { Donepezil } \\
5 \mathrm{mg}\end{array}$ & $\begin{array}{l}\text { Memantine } \\
15 \mathrm{mg}\end{array}$ \\
\hline 85 & $\begin{array}{l}\text { Dementia; } \\
\text { AD type, severe }\end{array}$ & $\begin{array}{l}\text { CRI, osteoarthritis, recurrent } \\
\text { UTI, dejenarative joint disease, } \\
\text { hypertension, stress urinary } \\
\text { incontinence, chronic leg edema }\end{array}$ & no & $\begin{array}{l}\text { Gabapentin } \\
300 \mathrm{mg}\end{array}$ & $\begin{array}{l}\text { Olanzapine } \\
7.5 \mathrm{mg}\end{array}$ & & \\
\hline 64 & $\begin{array}{l}\text { Dementia; } \\
\text { AD type, severe }\end{array}$ & $\begin{array}{l}\text { DM type II, seizure disorder, } \\
\text { tinea corporis of the right buttock, } \\
\text { anemia of chronic disease }\end{array}$ & no & $\begin{array}{l}\text { Gabapentin } \\
1200 \mathrm{mg}\end{array}$ & $\begin{array}{l}\text { Valproic acid } \\
1250 \mathrm{mg}\end{array}$ & & \\
\hline 83 & $\begin{array}{l}\text { Dementia; } \\
\text { vascular type, } \\
\text { moderate }\end{array}$ & $\begin{array}{l}\text { hypertension, CAD, CHF, } \\
\text { anemia, NIDDM, hyperlipidemia }\end{array}$ & no & $\begin{array}{l}\text { Gabapentin } \\
100 \mathrm{mg}\end{array}$ & $\begin{array}{l}\text { Quetiapine } \\
150 \mathrm{mg}\end{array}$ & $\begin{array}{l}\text { Donepezil } \\
10 \mathrm{mg}\end{array}$ & $\begin{array}{l}\text { Citalopram } \\
30 \mathrm{mg}\end{array}$ \\
\hline 64 & $\begin{array}{l}\text { Dementia; } \\
\text { vascular type, } \\
\text { moderate }\end{array}$ & $\begin{array}{l}\text { hypertension, CAD, DM, post } \\
\text { bilateral above knee amputation, } \\
\text { MRSA and vancomicyn } \\
\text { resistant enterococci wound } \\
\text { infection left thigh }\end{array}$ & no & $\begin{array}{l}\text { Gabapentin } \\
400 \mathrm{mg}\end{array}$ & $\begin{array}{l}\text { Risperidole } \\
2.5 \mathrm{mg}\end{array}$ & $\begin{array}{l}\text { Donepezil } \\
5 \mathrm{mg}\end{array}$ & $\begin{array}{l}\text { Valproic acid } \\
1000 \mathrm{mg}\end{array}$ \\
\hline 68 & $\begin{array}{c}\text { Dementia; mixed } \\
\text { type (AD and } \\
\text { alcohol induced), severe }\end{array}$ & BPH, hypercholesterolemia & $\begin{array}{l}\text { History of } \\
\text { alcohol } \\
\text { dependence }\end{array}$ & $\begin{array}{l}\text { Gabapentin } \\
1200 \mathrm{mg}\end{array}$ & $\begin{array}{l}\text { Olanzapine } \\
10 \mathrm{mg}\end{array}$ & $\begin{array}{l}\text { Donepezil } \\
10 \mathrm{mg}\end{array}$ & \\
\hline 78 & $\begin{array}{l}\text { Dementia; } \\
\text { AD type, severe }\end{array}$ & $\begin{array}{l}\text { hypertension, hyperthyroidism, } \\
\text { NIDDM }\end{array}$ & no & $\begin{array}{l}\text { Gabapentin } \\
900 \mathrm{mg}\end{array}$ & $\begin{array}{l}\text { Quetiapine } \\
25 \text { mg prn }\end{array}$ & $\begin{array}{l}\text { Donepezil } \\
10 \mathrm{mg}\end{array}$ & \\
\hline 79 & $\begin{array}{l}\text { Dementia; mixed } \\
\text { type, severe }\end{array}$ & $\begin{array}{l}\text { chronic pain, CVA, post UTI, } \\
\text { fungal groin infection }\end{array}$ & no & $\begin{array}{l}\text { Gabapentin } \\
600 \mathrm{mg}\end{array}$ & $\begin{array}{l}\text { Memantine } \\
5 \mathrm{mg}\end{array}$ & & \\
\hline 67 & $\begin{array}{l}\text { Dementia; AD } \\
\text { type, severe }\end{array}$ & $\begin{array}{l}\text { hypertension, bronchitis, GERD, } \\
\text { hypocholesterolemia, Raynaud's } \\
\text { disease, post lung ca, post left } \\
\text { lung-upper lobe lobectomy }\end{array}$ & no & $\begin{array}{l}\text { Gabapentin } \\
400 \mathrm{mg}\end{array}$ & $\begin{array}{l}\text { Clozapine } \\
200 \mathrm{mg}\end{array}$ & $\begin{array}{l}\text { Valproic acid } \\
500 \mathrm{mg}\end{array}$ & \\
\hline 82 & $\begin{array}{l}\text { Dementia; AD } \\
\text { type, severe }\end{array}$ & arthritis & no & $\begin{array}{l}\text { Gabapentine } \\
200 \mathrm{mg}\end{array}$ & $\begin{array}{l}\text { Quetiapine } \\
75 \mathrm{mg}\end{array}$ & & \\
\hline 81 & $\begin{array}{l}\text { Dementia; AD } \\
\text { type, severe }\end{array}$ & $\begin{array}{l}\text { hypertension, BPH, history } \\
\text { of diverticulosis }\end{array}$ & no & $\begin{array}{l}\text { Gabapentin } \\
600 \mathrm{mg}\end{array}$ & $\begin{array}{l}\text { Quetiapine } \\
200 \mathrm{mg}\end{array}$ & $\begin{array}{l}\text { Donepezil } \\
10 \mathrm{mg}\end{array}$ & \\
\hline 84 & $\begin{array}{l}\text { Dementia; mixed type } \\
\text { (AD and } \\
\text { Vascular) }\end{array}$ & $\begin{array}{l}\text { delirium due to multiple medical } \\
\text { causes, NIDDM, rapid AF, } \\
\text { hypothyroidism, chronic anemia, } \\
\text { post epidural hematoma, } \\
\text { post left breast mastectomy }\end{array}$ & no & $\begin{array}{l}\text { Gabapentin } \\
1200 \mathrm{mg}\end{array}$ & $\begin{array}{l}\text { Quetiapine } \\
200 \text { mg }\end{array}$ & $\begin{array}{l}\text { Donepezil } \\
5 \mathrm{mg}\end{array}$ & \\
\hline
\end{tabular}




\section{Continued}

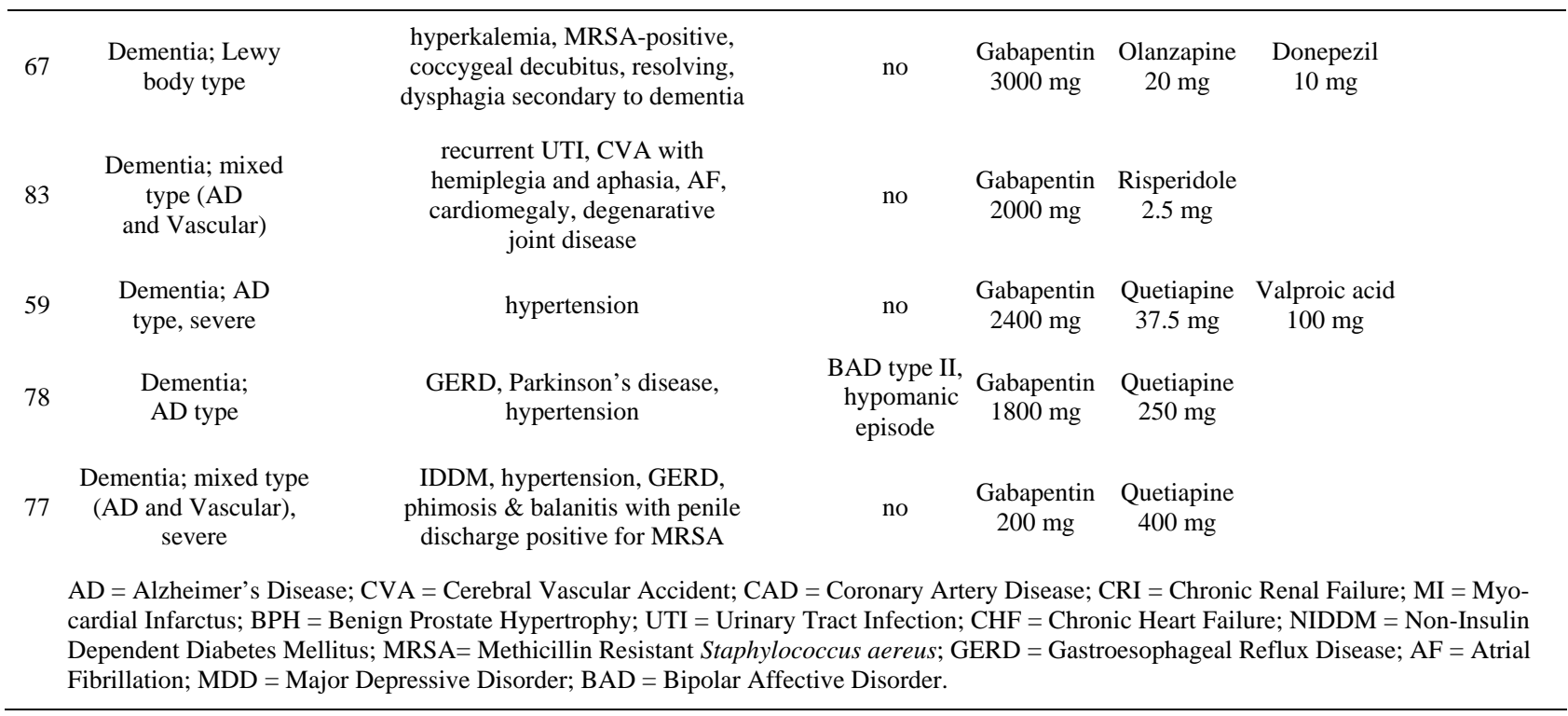

psychotic medication and gabapentin, which appears to be effective and well tolerated in the treatment of BPSD. Gabapentin was also effective as monotherapy for the treatment of two cases of BPSD. Side-effect profile was relatively benign and no drug-drug interactions were noted. Our finding is in keeping with the case-series by Moretti et al. [6], Herrmann et al. [7], where they found that gabapentin monotherapy was well tolerated and effective for the treatment of BPSD. However, our study also indicated that gabapentin was well tolerated even in combination with atypical antipsychotics.

As this study is a retrospective chart review and has potential for bias, further controlled studies are necessary to confirm the efficacy of the combination treatments for BPSD. However, this current study provides the proof that elderly patients with BPSD tolerate a combination of psychotropic medications, if these medications are dosed appropriately and monitored carefully.

\section{Conclusion}

Behavioral and psychological symptoms are common in dementia. The treatment for these important symptoms is not standardized and is limited by the side-effect profile of the various drugs. Gabapentin, an anticonvulsant medication may be beneficial in combination with antipsychotic agents or as monotherapy for patients presenting with these behaviors.

\section{REFERENCES}

[1] Barucha, A.J., Rosen, J., Mulsant, B.H. and Pollock, B.G. (2002) Assessment of behavioral and psychological symptoms of dementia. CNS Spectrums, 7, 797-802.

[2] Lawlor, B. (2002) Managing behavioural and psychological symptoms in dementia. British Journal of Psychiatry, 12, 463-465. doi:10.1192/bjp.181.6.463

[3] Tampi, R.R. and Van Dyck, C.H. (2006) Behavioral and psychological symptoms of Alzheimer's disease. In: Miao-Kun, S., Ed., Research Progress in Alzheimer's Disease, Nova Science Publishers, Hauppauge, New York, 245-258.

[4] Sink, K.M., Holden, K.F. and Yaffe, K. (2005) Pharmacological treatment of neuropsychiatric symptoms of dementia: A review of the evidence. Journal of American Medical Association, 293, 596-608.

doi:10.1001/jama.293.5.596

[5] Birnbaum, A.K. (2007) Pharmacokinetics of antiepileptic drugs in elderly nursing home residents. International Review of Neurobiology, 81, 211-220. doi:10.1016/S0074-7742(06)81013-5

[6] Moretti, R., Torre, P. and Rodolfo, M.A., et al. (2003) Gabapentin for the treatment of behavioural alterations in dementia. Drugs Aging, 20, 1035-1040.

[7] Herrmann, N., Lanctot, K. and Myszak, M. (2000) Effectiveness of gabapentin for the treatment of behavioral disorders in dementia. Journal of Clinical Psychopharmacology, 20, 90-93. doi:10.1097/00004714-200002000-00015

[8] Quick Reference to the Diagnostic Criteria from DSM-IV-TR $^{\mathrm{TM}}$ (2000) American Psychiatric Association, Washington DC, 88-95.

[9] Folstein, M., Folstein, S. and McHugh, P. (1975) Minimental state: A practical method for grading the cognitive state of patients for the clinician. Journal of Psychiatric Research, 12, 189-198. doi:10.1016/0022-3956(75)90026-6 